\title{
A LABDARÚGÓMÉRKŐZÉSEK LÁTOGATÁSI MOTIVÁCIÓJÁNAK VIZSGÁLATA A DEAC CSAPATÁNAK PÉLDÁJÁN KERESZTÜL
}

\author{
INVESTIGATION OF THE MOTIVATION OF THE SUPPORTERS IN SOCCER MATCHES IN THE \\ EXAMPLE OF DEAC
}

Bács Zalán Mihály, Lente Lajos

Debreceni Egyetem, Sporttudományi Koordinációs Intézet

\begin{abstract}
Összefoglaló
Jelen tanulmányban a Debreceni Egyetemi Atlétikai Club labdarúgó mérkőzéseit látogatók motivációját vizsgáltuk. Kutatási módszerként kérdőívet használtunk, amelyben Kajos et al. (2017) SPEED-H skáláját is alkalmaztuk. A kérdőivet hólabda módszerrel online formában juttattuk el a célcsoporthoz, a minta nagysága 40 fó, akik nagyobbrészt a Debreceni Egyetem hallgatói, dolgozói. A válaszadók többsége 2-10 éve látogatja a DEAC mérkőzéseit. Az eredmények alapján megállapítható, hogy elsô alkalommal a sport szeretete miatt és a barátok hatására látogattak ki a DEAC mérkőzésére. A SPEED-H skála szerint a válaszadók számára legfóbb motiváló erôvel a játék szépsége és izgalma rendelkezik.
\end{abstract}

Kulcsszavak: sportrendezvény látogatási motiváció, labdarúgás, SPEED-H skála

\begin{abstract}
In this study, We've been examining the motivation of the fans of the Debreceni Egyetemi Atlétikai Club. We chose the questionnaire as a research method in which We used the SPEED-H scale developed by Kajos et al. (2017). We sent the questionnaire online to the target group by the snowball method, the sample was 40 people, mainly students, workers, and teachers of the University of Debrecen. The majority of the repliers are visiting DEAC matches for 2-10 years. It turned out that the reason for their first visit was the love for the sport and the effect of their friends. According to the SPEED-H scale, the main motivation for the repliers to visit was the excitement and beauty of the game.
\end{abstract}

Key words: sports motivation, soccer, SPEED-H scale

\section{BEVEZETÉS}

A sportrendezvények látogatása a szórakoztatóipar részévé vált. Számos tanulmány vállalkozott a sportrendezvények nézettségének feltérképezésére. Mind hazai, mind nemzetközi kutatások foglalkoznak egyéni és csapatsportágak sportrendezvényeinek szurkolói motivációjával. Sportolói múltam a Debreceni Egyetemi Atlétikai Club labdarúgó szakosztályához köt. A DEAC felnőtt csapata az idei bajnokságban az NB3 Keleti csoportjában versenyez, amelynek köszönhetően vélhetően több szurkoló látogat ki a csapat mérkőzéseire. A DEAC család tagjaként az egyetemi klub labdarúgócsapatának mérkőzéseit látogatók motivációs vizsgálatára vállalkozok. Célom, hogy eredményeimmel segítsem az egyesületet szurkolói bázisának növelésében. 


\section{SZAKIRODALMI ÁTTEKINTÉS}

„Pszichológiai megközelítése szerint a motiváció egy belső tudatállapot, az emberi tevékenységek ösztönzését értjük alatta (ROÓZ - HEIDRICH, 2013).

Eredetük szerint vannak primer (biológiai motívumok) és szekunder (személyes és társas) motívumok. A szükségletek kielégítése szerint organikus és pszichés, az aktuális tudat állapot szerint tudat alatti és tudatos, a kihatásra való terület szerint tudás, művészet, sport stb. motívumok (FEJES, 2015). A cselekvést kiváltó erők forrása szerint belülről fakadó (intrinzik) és kívülről fakadó (extrinzik) motivációkat különböztethetünk meg. A motiváció okozati, kauzális megközelítése a múltbeli események hatására, míg a célra irányuló, azaz finális megközelítés a cselekvés jövőbeli következményeire fókuszál (GŐSINÉ GREGUSS-BÁNYAI, 2006; FEHÉR ET AL., 2019)”.

A sportesemények potenciális nézőjének motivációját sok szerző megpróbálta tisztázni. Darmon et al. (1982) átvette Maslow elméletét a szükségletek hierarchiájáról és alkalmazta azt a sportra. Maslow (1954) szerint a szükségletek hierarchikusan épülnek fel, és az alsóbb szinten lévőket előbb kielégítve merül csak fel a következő szintű szükséglet kielégítésének igénye. A fiziológiai szükségleteket a biztonsági, majd a közösségi és az önmegvalósítási szükségletek követik. Darmon et al. (1982) a sportszükségleteket a közösségi szükségletekhez sorolták, és kifejlesztettek egy speciális sport-szükséglet piramist, amelyen legalul az energia felesleg elhasználása található, ami felett az egészség biztosítása, majd a csoporthoz tartozás és végül a rajongás, a pihenés és a szabadidő eltöltése következik ( CORREIA-ESTEVEZ, 2007).

A sportesemények nézőinek motivációját számos kutatás vizsgálta. Egyes kutatások beazonosították az „igazi szurkolókat”. Brokaw (2000) jellemzi őket és megállapítja, hogy intenzív érzelmi reakciókat mutatnak a követett sportcsapat, vagy a sportoló iránt. Ők a leghűségesebb mérkőzéslátogatók, sem az eredmény (illetve eredménytelenség), sem a helyszíni vagy pénzügyi nehézségek nem tartják őket vissza. Zhang et al. (1997) az alkalmi szurkolók mellett érvel azzal, hogy a sportrendezvények bevételeinek nagy része mégis csak tőlük származik. Ross et al. (2006) úgy jellemzi ezt a nézői csoportot, mint amelyet a reklámok erőteljesen befolyásolnak (HALL ET AL., 2010). Dietz-Uhler és társai (2000) felhívják a figyelmet arra, hogy a helyszíni nézők számát a TV közvetítések is csökkenthetik.

Dietz-Uhler és munkatársai 2000-ben végzett kutatásuk során arra a következtetésre jutottak, hogy a sporteseményeken való részvétel a családdal és a barátokkal való szocializáció lehetőségével is összefüggésbe hozható (DIETZ-UHLER ET AL. 2000).

A sport érzelmi, izgalmi élményszerűségét is sok kutató igazolta (KAHLE-RILEY, 2004; HALL ET AL., 2010).

Wann (1995) és Al-Thibiti (2004) szerint a nézők azért mennek sporteseményre, mert ez ad lehetőséget nekik arra, hogy kiszakadjanak a mindennapi élet rutinjából. Kahle és Riley (2004) kifejti, hogy sok résztvevő „kevésbé foglalkozik a sportesemény kimenetelével, mint a szórakoztatási élmény általános minőségével" (HALL ET AL., 2010).

Több kutatás a szolgáltatás-kínálat elemivel köti össze a sportesemény látogatási motivációt. Ide a szolgáltatás minőségét, a helyszín tisztaságát, a mellékhelyiség 
rendelkezésre állását, ételek - italok, valamint a parkoló elérhetőségét (WAKEFIELD BLODGETT, 1996; WAKEFIELD - SLOAN, 1995) sorolják. Ezen kívül természetesen maga a sportlétesítmény is nagy hatással van a látogatottságra. A sport rendezvény helyszínéhez kapcsolódóan a kutatások kiemelik, hogy a nézők a részvételi döntéseik során olyan kérdéseket vesznek figyelembe, mint a méret, az ülőhely kényelme és hozzáférése, valamint a stadion esztétikai tulajdonságai (FINK ET AL, 2002).

Hall et al. (2010) összegyüjtve a korábbi kutatások tapasztalatait megalkotják a sportrendezvények részvételi motivációjának empirikus modelljét. A szakirodalomban talált sportesemény látogatással kapcsolatos kutatások tényezőit faktor analízissel fejlesztették tovább, ahol a következő faktorokat azonosítják be:

1. Érzelmi-izgalmi tényező: A néző érzelmeinek felkeltése a sportesemény megdöbbentő, vagy felrázó, izgalmas voltával.

2. Hát-tér tényező: minden olyan tényező, amely hozzájárulhat az általános élményszerzéshez, ideértve a parkolást és a könnyű megközelíthetőséget.

3. Igazi szurkoló/rajongó tényező: azok a résztvevők, akiknek a játék élvezete a legfontosabb. Érdekli őket az esemény, az eredmény, az általuk támogatott csapat vagy egyén teljesítménye.

4. Front tényező: a sportrendezvény olyan elemei, amelyek a menedzsment ellenőrzése alatt állnak, például a catering, vagy az általános tisztaság.

5. Szociális tényező: a barátok és a család fontossága az esemény élvezetében.

6. Alternatív lehetôségek: A helyszíni részvételt befolyásolhatja, hogy a játékot televízióban közvetítik, illetve a csapat sikere.

Az 1. ábra Hall és társai (2010) sportesemény látogatottsági motivációijának modelljét grafikusan mutatja be.

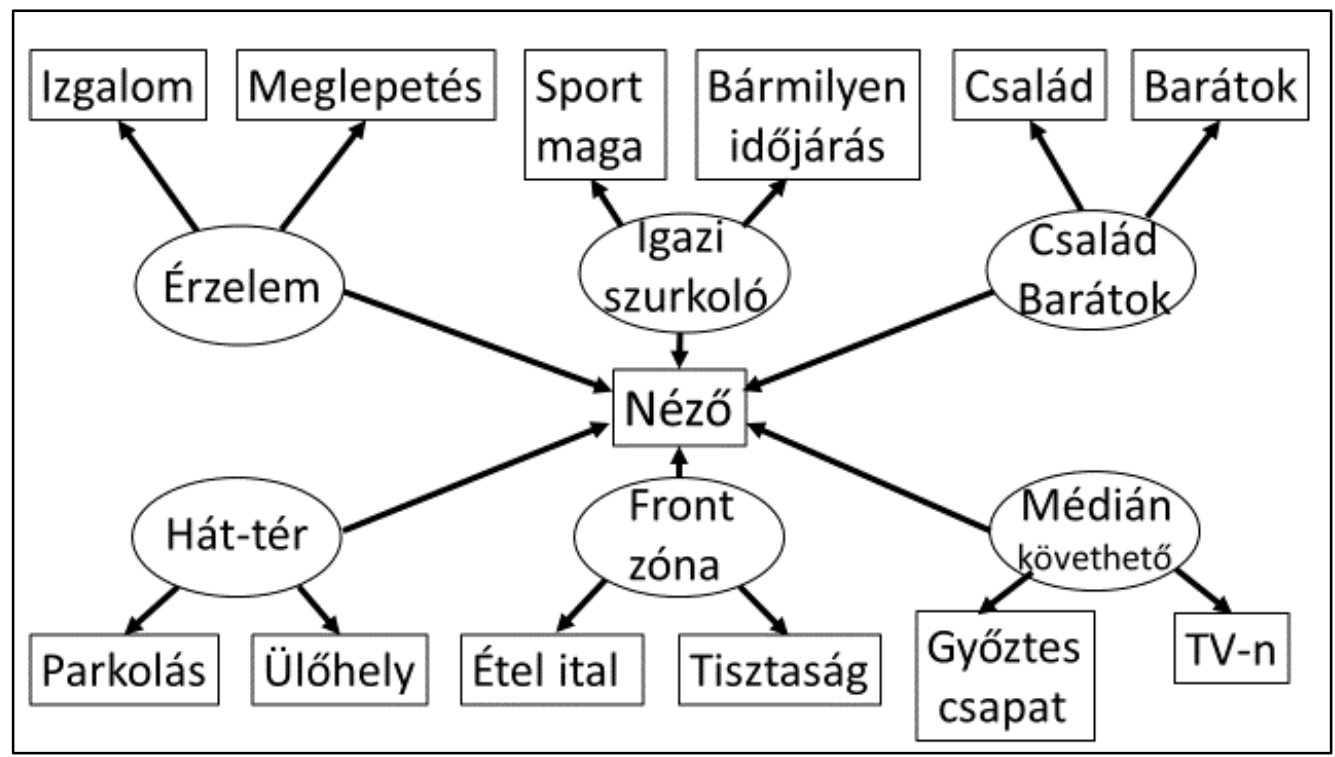

1. ábra: A sportrendezvények részvételi motivációjának empirikus modellje Forrás: Hall et al., 2010.

Hazai kutatások is vizsgálták a nézettség alakulását. A labdarúgó mérkőzések nézőinek motivációját vizsgálta Kajos et al. (2017). Funk és társai által 2009-ben létrehozott SPEED 
skálát magyarosították és validálták. A SPEED mozaikszó: az angol Socialization (Társas kapcsolatok iránti igény), Performance (Teljesítmény), Excitement (Izgalomkeresés), Esteem (Önbecsülés) és Diversion (kikapcsolódás/elmenekülés) elnevezésű faktorok kezdőbetűiből jött létre. A skála minden egyes faktora két-két kérdést tartalmaz, amelyek együttesen alkotják a skálát (KAJOS ET AL., 2017). A magyar kutatók a SPEED skálát pilot kutatásuk alapján kiegészítették még az esztétikum tényezőjével. Eredményeik alapján látszik, „,hogy más tényezők válnak fontossá a demográfiai változók és mások a viselkedési változók kapcsán. Vagyis a különböző indíttatásból szurkolók számára különböző igények teljesítése révén biztosítható a fogyasztói élmény (KAJOS ET AL., 2017).

\section{ANYAG ÉS A MÓDSZER}

Kutatási módszernek a kérdőíves vizsgálatot választottuk. Az általunk szerkesztett kérdőív első része demográfiai adatok felmérésére szolgál (a válaszadók neme, életkora, lakhelye, végzettsége, családi állapota).

Mérőeszközünk második része sportrendezvény látogatási motivációt mérő szakmai kérdésekből áll. Ebbe a részbe beépítettük Kajos és társai (2017) által adaptált és validált SPEED-H kérdőív kérdéseit.

Kérdőívünket a DEAC labdarúgó szakosztály szurkolóihoz online formában juttattuk el. 40 válaszadótól gyüjtöttük be az adatokat. A válaszadók 22,5\%-a (10 fő) nő, 77,5\%-a (30 fó) férfi volt. Életkori megoszlásukat a 2. ábra mutatja be. Eszerint a kitöltők döntő többsége (57,5\%) 21-30 év közötti.

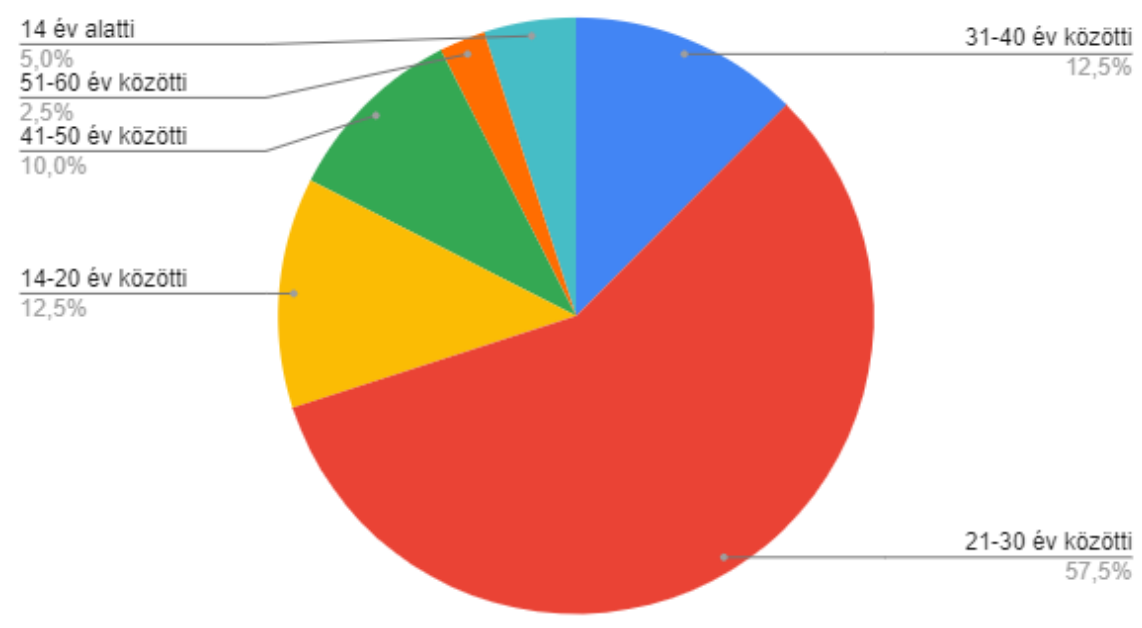

2. ábra: A minta életkor szerint megoszlása

Forrás: saját szerkesztés

Családi állapotukat tekintve a válaszadók 32,5\%-a egyedül, a többi válaszadó 1-5 fôvel közös háztartásban él. A lakóhely szerinti megoszlás azt mutatta, hogy 5\%-uk fôvárosi, 62,5\%-uk megyeszékhelyi, 30\%-uk városi és 2,5\%-uk községi lakos. Legmagasabb iskolai végzettség alapján 55\%-uk érettségivel, 12,5\%-uk főiskolai, 30\%-uk egyetemi diplomával rendelkezik, 2,5\%-uk még általános iskolás. A megkérdezettek több, mint fele $(52,5 \%)$ tanuló, 40\%-uk szellemi munkát, míg 7,5\%-uk fizikai munkát végez. 


\section{EREDMÉNYEK}

A kérdőívet kitöltők 17,5\%-a a mérkőzések látogatási gyakoriságával kapcsolatban azt nyilatkozta, hogy 5-nél kevesebb mérkőzésen, 45\%-a 5-10 mérkőzésen, 37,5\%-a pedig minden vagy majdnem minden mérkőzésen részt vesz egy bajnoki idény alatt. $\mathrm{A}$ válaszadók közül mindössze 5 fő $(12,5 \%)$ jár idegenbeli mérkőzésre is. A 3. ábra azt mutatja, hogy mióta látogatják a válaszadók a DEAC mérkőzéseit. A kérdésekre adott válaszok alapján megállapítható, hogy többségében már több éve a csapat szurkolói (70\%), 15\%-uk az előző idényben, 15\%-uk pedig ebben az idényben csatlakozott a szurkolókhoz (3. ábra).

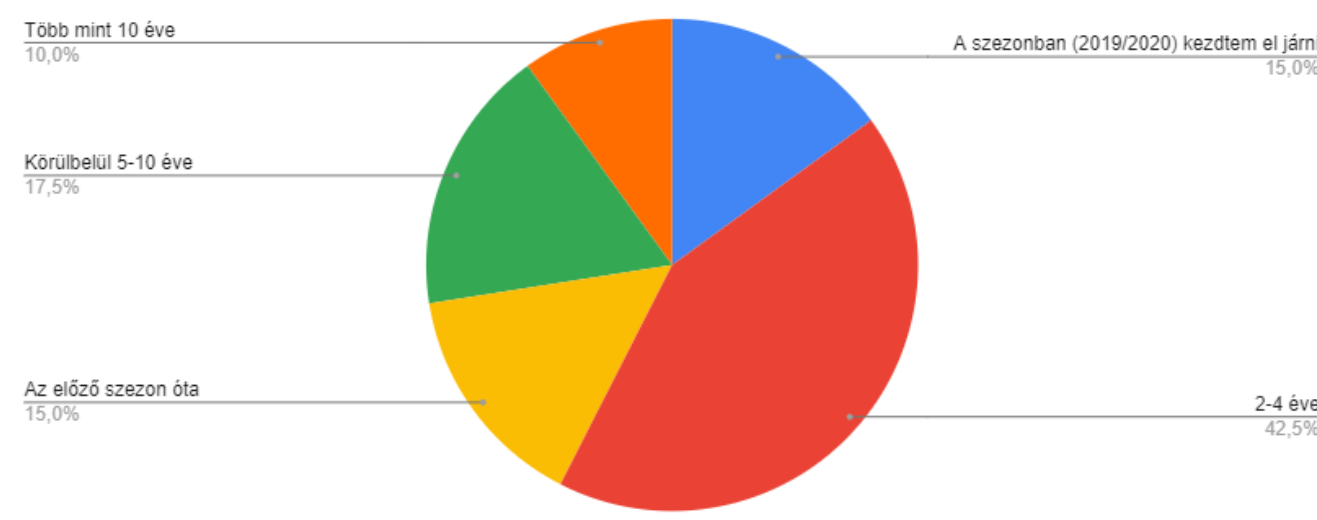

3. ábra: A minta megoszlása a DEAC mérkőzések látogatásának elkezdési ideje szerint Forrás: saját szerkesztés

Kíváncsiak voltunk arra is, hogy miért látogattak ki első alkalommal a DEAC csapatának mérkőzésére. Amint azt a 4. ábra mutatja, leginkább a sport szeretete és a barátok voltak a meghatározó motiváló tényezők.

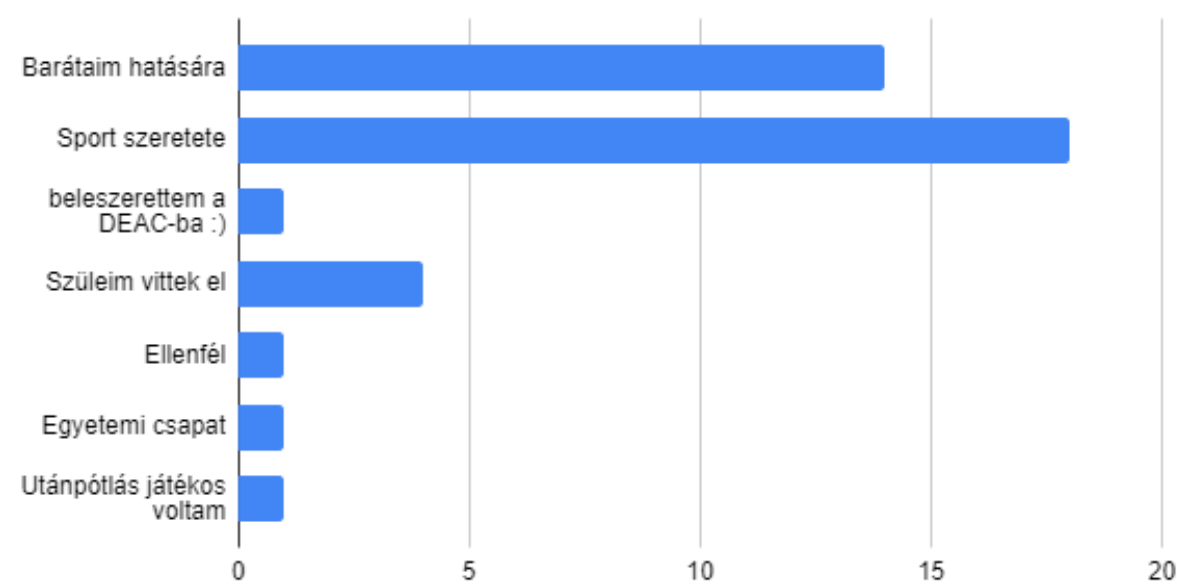

4. ábra: Az elsô mérkőzéslátogatás motivációja a mintában Forrás: saját szerkesztés

Arra a kérdésre, hogy kiknek a társaságában látogatják a DEAC mérkőzéseit a válaszadók 92,5\% jelölte meg a barátait és csak 7,5\%-uk jár másokkal mérkőzésekre. 
Az 1. táblázat a Speed-H skála eredményeit mutatja be a mintában. A SPEED-H skála tényezőinek értékelése úgy alakult, hogy a DEAC mérkőzéseket látogatók számára a legfontosabb tényezők az esztétikum és az izgalomkeresés volt. Legkevésbé a kikapcsolódás vagy elmenekülés jelent motiváló erőt a válaszadók számára. Az esztétikum előtérbe kerülése megerősíti Kajos et. al. (2017) döntését a tényezőnek a skálába való beillesztésében.

1. táblázat: A SPEED-H skála eredményei a mintában

\begin{tabular}{|l|l|l|l|l|}
\hline SPEED-H tényezők & $\begin{array}{l}\text { első item } \\
\text { átlaga }\end{array}$ & $\begin{array}{l}\text { második } \\
\text { item átlaga }\end{array}$ & $\begin{array}{l}\text { a tényező } \\
\text { átlaga }\end{array}$ & rangsor \\
\hline $\begin{array}{l}\text { Társas kapcsolatok iránti } \\
\text { igény }\end{array}$ & 3,28 & 3,8 & 3,54 & 5. \\
\hline Teljesítmény & 3,68 & 3,61 & 3,65 & 4. \\
\hline Önbecsülés & 4,05 & 4,04 & 4,04 & 3. \\
\hline Izgalomkeresés & 4,56 & 4,17 & 4,37 & 2. \\
\hline Kikapcsolódás/elmenekülés & 2,78 & 3,51 & 3,14 & 6. \\
\hline Esztétikum & 4,31 & 4,54 & 4,42 & 1. \\
\hline
\end{tabular}

\section{ÖSSZEGZÉS}

Jelen tanulmányban a Debreceni Egyetemi Atlétikai Club labdarúgó mérkőzéseit látogatók motivációját vizsgáltuk. Vizsgálati módszerként kérdőívet alkalmaztunk, amelyben Kajos et al. (2017) SPEED-H skáláját is felhasználtuk. Az online terjesztett kérdőívet 40-en töltötték ki, nagyobbrészt a Debreceni Egyetem hallgatói, dolgozói akiknek nagyrésze már több éve a csapat szurkolója. Az eredmények arra világítottak rá, hogy első alkalommal a sport szeretete miatt és a barátok hatására látogattak ki a DEAC mérkőzésére. A válaszadók 92,5\%-a azóta is barátai társaságában jár a mérkőzésekre és élvezi a játék látványát. A SPEED-H skála esetében a társas kapcsolatok iránti igény kevésbé bír motiváló erővel, hiszen már kialakult baráti társaságok látogatják a mérkőzéseket és számukra nagyobb motiváló erőt jelent a mérkőzésekre való kilátogatásban a játék szépsége és izgalma.

A publikáció elkészítését az EFOP 3.6.116201600022 „Debrecen Venture Catapult Program” projekt támogatta. A projekt az Európai Unió támogatásával, az Európai Szociális Alap társfinanszírozásával valósult meg. 


\section{IRODALOMJEGYZÉK}

Al-Thibiti, Y. (2004). A scale development for sport fanmotivation (unpublished thesis), Department of SportManagement, Florida State University.

Brokaw, A. (2000). An explanation of attendance in Division II college football, Cyber Journal of Marketing, 4, (2-3).

Correia, S., Esteves (2007). An exploratory study of spectators' motivation in soccer. International Journal of Sport Management and Marketing, 2, (5/6).

Darmon, R., Laroche, M. \& Pétrof, J. (1982). Le Marketing: Fondements et Applications. Montréal: McGraw-Hill.

Dietz-Uhler, E. A. Harrick, C. E., \& Jacquemontte L. (2000). Sex differences in sport fan behaviour and reasons for being a sport fan. Journal of Sport Behaviour, 23, 219-231.

Fehér A., Bácsné Bába É., Müller A., \& Szakály Z. (2019). Fizikai aktivitás motivációival kapcsolatos modellek rendszerezése. I. Egészségpiaci Kutatások lektorált tanulmánykötet, Debrecen, 152-164.

Fejes J. B. (2015). Célok és motiváció - tanulási motiváció a célorientációs elmélet alapján. Gondolat kiadó, Budapest.

Fink J. S., Trail G. T., \& Anderson D. F. (2002). Environmental factors associated with spectator attendance and sport consumption behaviour: gender and team differences. Sport Marketing Quarterly, 11, (1).

Gősiné Greguss A., Bányai É. (2006). A motiváció. In Oláh A. (szerk.) Pszichológiai alapismeretek. Bölcsész Konzorcium, 321-369.

Hall J., O'Mahony B., \& Viecelia J. (2010). An empirical model of attendance factors at major sporting events. International Journal of Hospitality Management, 29, (2), 328-334.

Kahle, L. \& Riley, C. (2004). Sports marketing and thepsychology of marketing communication. New Jersey: Lawrence Erlbaum Associates Inc. 
Kajos A., Prisztóka Gy., \& Pais A. (2017). A nézőtéri sportfogyasztás motivációt mérő, magyar nyelvű SPEED-H skála validációja és néhány eredménye. Vezetéstudomány / Budapest Management Review XLVIII, (10), 19-31.

Maslow A. H. (1954). Motivation and personality. Harpers.

Roóz J., Heidrich B. (2013). Vállalati gazdaságtan és menedzsment alapjai. Budapest, Budapesti Gazdasági Főiskola.

Ross, S. (2006). A conceptual framework for understanding spectator-basedbrand equity. Journal of Sport Management, 20,(1), 22-38.

Wakefield, K., Blodgett, J. (1996) The effect of the servicescape on customers behavioural intentions in leisureservice settings, Journal of Services Marketing, 10, (6), 45-61.

Wakefield, K., Sloan, H. (1995) The effect of team loyalty andselected stadium factors on spectator attendance, Journal of Sport Management, 9, (3), 153-172.

Wann, D. (1995). Preliminary validation of the sport fan motivation scale. Journal of Sport and Social Issues, 19, (4), 377-39.

Zhang, J., Smith, D., Pease, D., \& Jambor, E. (1997). Negative influence on market competitors on the attendance of professional sport games: the case of a minor league hockeyteam, Sport Marketing Quarterly, 6, (3), 31-40. 